\title{
Exploring Appropriation of Global Cultural Rituals
}

Dr Julie Tinson

Senior Lecturer

Marketing Division

Stirling Management School

University of Stirling

Stirling

FK9 4LA

Telephone: 01786467389

Fax: 01786464745

Email: j.s.tinson@stir.ac.uk

$\&$

Dr Peter Nuttall

School of Management

University of Bath

Bath BA2 7AY

UK

Telephone: 01225386742

Fax: 01225386473 


\begin{abstract}
Adolescents, as a consequence of identification with popular culture, have been described as having homogenous consumption patterns. More recently, however, it has been recognised that 'glocalisation' (global practices reworked to fit local contexts) affords an opportunity for differentiation. This paper considers a recent UK phenomenon, namely that of the US high school prom, and seeks to explore the ways in which this ritual has been adopted or adapted as part of youth culture. The method employed here was mixed methods and included in-depth interviews with those who attended a prom in the last three years as well as a questionnaire distributed amongst high school pupils who were anticipating a high school prom. The findings illustrate that the high school prom in the UK is becoming increasingly integrated into the fabric of youth culture although, depending on the agentic abilities employed by the emerging adults in the sample, there is differing appropriation of this ritual event particularly in relation to attitudes towards and motivations for attending the prom. A typology of prom attendees is posited. This paper contributes to our understanding of this practice in a local context.
\end{abstract}

\title{
Key Words
}

Appropriation, Youth Culture, Rituals, Agency and Glocalisation

\section{Biographies}

Dr Julie Tinson is a Senior Lecturer in Marketing at the University of Stirling where she principally teaches Consumer Behaviour and Marketing Communications. Her research interests include family decision making and consumer socialisation. She has published widely on consumer behaviour in relation to families and children and has recently written a book on how to research with children and adolescents. Consultancy includes work for Associa (NFU), Barclays Bank, Tpoll and Channel 4.

Dr Peter Nuttall is a Lecturer in Marketing in the School of Management at the University of Bath. He teaches in the areas of international marketing and marketing communications and is also a visiting associate professor at Malta University. His publications have been focused primarily in the field of adolescent and young consumer behaviour. More specifically his research has explored the consumption and use of popular music as a means of expressing identity and the impact of family structure and peer group affiliation on this consumption behaviour. Consultancy work has centred on consumer market research in the charity and not-for-profit sector. 


\section{Introduction}

Ritualized activities and events that symbolise important and meaningful life experiences are regularly practised by consumers (Ruth, 1995). Interest in such events have led consumer researchers to explore the role of rituals by considering, amongst others, special holidays; Halloween, Christmas, Valentine’s Day (See Belk, 1990; Pollay, 1987; Close \& Zinkhan, 2006), life changing events; marriage, divorce, birth, death (See Otnes \& Lowrey, 1993; McAlexander,1991; Ozanne, 1992; Bonsu, 2001), personal experiences; body art, grooming and car consumption (Watson, 1998; Rook \& Levy, 1983; Belk, 2004) and shared occasions; gift giving, sporting events and food consumption [For example see Fischer \& Gainer, 1993; Chun, Gentry \& McGinnis, 2005]. Curiosity in ritual behaviour is also global (See Chun, Gentry \& McGinnis, 2004; Fernandez \& Veer, 2004) and in recent years, rituals practised in the US have been embraced more fully in the UK (e.g. Halloween) with the ensuing commercialisation and consumption behaviour associated with such practices increasingly apparent (Jeffries, 2004). However, the extent to which these rituals are being adapted as well as adopted is less well documented and needs further exploration.

\section{Globalization and Glocalisation}

Before considering the appropriation of rituals (in this particular case the high school prom) it is important to note that globalization and its affects are vigorously debated and that there are "many divergent views on the various aspects of globalization such as who the main players are, what it's manifestations are and whether this phenomenon is good or bad, culturally or economically and for whom” (Eckhardt and Mahi, 2004: 136). Multinational corporations and governments are in the context of 
business identified as the key players when considering economic policy and resource allocation (Prakash and Hart, 2000) and in the discipline of marketing, consumers and their role in and relationship with globalization have been of increasing interest. In 1993, Ritzer suggested that global consumer brands would change the culture in developing countries, consumers would be passive and that brands, products and the experiences of these would be homogenous. Ever since, the role of the consumer in globalization has since been contested with Arnould and Thompson (2005) suggesting consumers are interpretive agents rather than 'passive dupes'; supporting Ger and Belk’s (1996) definition of consumer agency as the ability of individuals and groups to transform and play with meaning.

Although it has been argued that cultural messages are differentially received and interpreted (Tomlinson, 1991) these local versions are still constrained within the boundaries of "global structural commonalities” (Kjeldgaard and Askegaard, 2006: 245). That is, consumers are not entirely free agents nor are they completely bound by social structures. If, as suggested, homogenization and heterogenization are commonly interconnected processes (Robertson, 1994; Robertson and White, 2005) then local interpretation is not without the influence of the global. Local cultures and the influences of globalization are 'co-shaping' (Thompson and Arsel, 2004) in this way and it is this that is at the core of glocalisation (See Robertson, 1995). Furthermore, Giulianotti and Robertson, (2007: 134) suggest that "glocalisation both highlights how local cultures may critically adapt or resist 'global' phenomena and reveals the way in which the very creation of localities is a standard component of globalization”. 


\section{Appropriation}

Mere exposure to global cultural practice does not constitute appropriation (Rogers, 2006). Whilst appropriation can be described as a group borrowing or imitating the design or practices of another to call them their own (Shugart, 1997; Ostergaard et al, 1999) this is not to say the appropriation of the design or practice is to distort or deconstruct its previous meaning and associated experiences. However, the appropriations process, “incorporates everything done to the product from the time of acquisition until it is no longer owned by the consumer” (Ostergaard et al, 1999: 406). In doing so the product, brand or ritual is either adopted or adapted but subsequently transformed to reflect its owner (s) where consumption can meet the needs of both social engagement and distinction. An aspect of this transformation will also involve negotiating authenticity (Arthur, 2006). As a consequence of glocalisation each culture has to define what is genuine, real or trustworthy.

\section{Youth Culture, Glocalisation and Appropriation}

Technology and media revolutions have transformed the lifestyles of young people on an international scale (Bynner, 1997) and young adults' identification with popular culture through mass media is arguably the most significant influence on young people’s consumption (Fien et al, 2008). This identification has been used to illustrate the impact of globalization on youth culture (Lukose, 2005) with the suggestion that there is little to differentiate the consumption patterns of adolescents across the developing world. Yet young people or those in emerging adulthood are free to explore their agentic abilities (Erikson, 1968) during this the period of transition. As such it is recognised that whilst youth consumption practices have been used to illustrate homogenization (Brake, 1985) more recent commentators have suggested 
that the youth market "interpret and rework global cultural practices and meanings to fit into local contexts” (Kjeldgaard and Askegaard, 2006: 231). The degree to which these global practices are reworked however will depend on both the individual and group agency of the adolescents. Kozinets et al (2004) discuss two opposing views on agency; one being that individuals can be creative and subversive, the other being that agency can be overwhelmed and duped by producers. Whilst it is likely that consumer and producer interests may overlap and that co-creation can exist in certain circumstances (e.g. rituals) it is also acknowledged that individual and even group resistant alternatives, particularly during adolescence, may be difficult to achieve. That is, although agency implies that the actors have the freedom to create, change and influence events, factors affecting agency include pre-conditions (e.g. individual goals), processes (e.g. locus of control within peer group/s or cultural boundaries) and previous agentic actions (Titma et al, 2007). This needs further exploration in the context of the adoption or adaptation of global rituals.

Arguably one of the most significant developmental aspects for an adolescent in the UK is leaving high school or sixth form to continue with further education and/or to find employment (See for example: Hektner, 1995). In order to recognise this milestone in the UK, traditionally there would have been a disco in the school gym (Pyke and Bloomfield, 2004) where pupils would be expected to perhaps invest in a new pair of jeans and some hair products. This has changed in recent years as Duffy (2007) suggests that although less than a decade ago 'proms' were an exclusive part of American life, in the past ten years it has become the ultimate coming of age celebration for adolescents living in the UK. The UK Government has also been said to encourage the US approach to end of school parties believing that formal 
ceremonies will help motivate students across the ability range (Pyke and Bloomfield, 2004).

In a global context, a number of coming of age celebrations are practised but often, contrary to the prom, these are associated with religious observances. The Bar Mitzvah, Confirmation and "na'ii'ees" (an apache rite of puberty) are illustrative of these. However, it may be that similar ritual elements observed as part of the high school prom will be evident in these practices. The Quinceañera, for example, is a traditional coming-of-age celebration for Latinas and is an elegant party on the girl's 15th birthday; highlighting God, family, friends, music, food and dance. Further exploration of these rituals in the context of glocalisation is also merited.

\section{The High School Prom}

The principle notion of the high school prom historically in youth culture has been to signal the transition of youths to adulthood. The school prom was inspired by the debutante ball which was of particular significance for young women as it signalled that they were ready for marriage (Escalas, 1993). The US high school prom in this respect is a more modern ritual although there continues to be more formal aspects to it. Girls wear formal dresses with a corsage given to them by their partner. Boys usually dress in black tie and traditionally girls give boys matching buttonholes to be worn on their suits. The high school prom can have a theme (e.g. that of a popular film). Common US high school prom activities include having photographs taken, dining, dancing, and the crowning of a prom king and queen (and having fun). The high school prom can be a meal in hotel followed by a nightclub or can simply be an event organised by a school committee and/or by members of the school staff in the 
gym hall. The girls are expected to have a partner and the partner is typically expected to pay for his partner's ticket to the event as well as his own.

Few scholars have used the high school prom to explore youth culture. Best (2000) notes that we have less systematic research on high school proms and the associated rituals and practices because they are typically dismissed as 'trivial'. She suggests research in this area would generate insight into transitional behaviour and argues that the high school prom has wrongly been positioned as 'marginal'. Escalas (1993) has also called for an examination of rites of passage present in modern day society (e.g. high school proms).

\section{Aspects of the Ritual Experience}

Ritual artefacts (signs and symbols), a ritual script, performance roles and an audience have been identified by Rook (1985) as essential to a ritual experience. Escalas (1993) observes that these four components are central to the debutante ball and they are in some respects equally relevant for the US high school prom. The gown, the meal, the photographs and the audience (internal and external) contribute to the overall event. Ritual artefacts, in particular, when used in a ritual context can convey specific symbolic messages. As the "activities of getting ready [for the prom] enabled many girls to demonstrate their skills at assembling a range of signs or symbols...in a way that transformed who they were at school” (Best, 2004:199) the school prom clearly plays a role in allowing attendees to "tell others who I am and what I want to be" (Ostergaard et al, 1999: 407). 
A ritual script appears to be in place for the high school prom although it is certainly not as rigorous as that of the debutante ball. Whilst there are specific components to it (e.g. corsage, dining, having photographs taken) there are more informal elements (e.g. type of dancing, colour and style of dress). The performance roles can also be adapted. It is commonplace to have a partner for a high school prom in the US (although not all attendees have someone to accompany them).

The audience is also now more diverse and virtual. With the proliferation of mobile phones with cameras, digital cameras and social networking sites the opportunity to illustrate this aspect of youth culture is vast. The high school prom has not only risen in popularity but has transcended continents. How, if at all, has the high school prom been adopted or adapted in the UK and how does consumer agency affect the way in which this aspect of youth culture is translated and appropriated in the UK?

This study is designed to capture the practice of a recent phenomenon in the UK, namely that of the US High school prom. By exploring the high school prom as a ritual event, this paper will investigate if and/or how youth culture is a glocal phenomenon that depends on a dynamic cultural process of adoption and adaptation. This specific experience will be considered in an attempt to understand how this aspect of youth culture is translated and appropriated in the UK. The research reported here is an exploratory study conducted with both adolescents who currently attend a secondary school in central Scotland and young adults who have attended a high school prom in the UK in the last three years. In order to meet the aims of the research, the following objectives were set: 
- To explore the adoption and adaptation of the high school prom in the context of the homogenization of youth culture and to investigate if this global phenomenon impacts on local practice

- To develop a deeper understanding of the relationship between the components and the ritual experience in the context of an event that symbolises a rite of passage

- To examine the interpretation (and re-working) of the high school prom as a cultural practice and to appreciate the meaning of individual agency in this context

\section{Method}

This research employs a mixed method approach as described by Johnson \& Onwuegbuzie (2004). The method used here is a mixed model design which involves mixing qualitative and quantitative approaches within or across the stages of the research process. However it is recognized that "the distinction of phenomena in mixed methods research is crucial and can be clarified by labeling the phenomenon examined by each method” (Sale et al, 2002: 50). To that end, this is a qualitative study of the appropriation of the high school prom as a global ritual which informs a quantitative study of ritual practice. In order to further appreciate the significant findings of the questionnaire, the qualitative data is revisited to enhance our understanding of both agency and the appropriation of this cultural event. Consumer culture theorists have a commitment to multi method investigations (Arnould and Thompson, 2005) and the approach used here supports the view of Moran-Ellis et al., (2006) who suggest mixed methods allows an in depth exploration and integration of data and posit that when employing mixed methods data it would appear to be 
important to focus on what needs to be found out as opposed to the type of method which provided the answer.

Initially twelve interviews were organized with young adults (18-20 years of age) who had already attended a high school prom (and the sample included those from England, Ireland and Scotland). A semi-structured interview guide was developed for the data collection phase. Questions ranged from an initially broad approach with questions such as 'tell me about your school prom' with later questions addressing the specific aspects of the prom as a ritual such as 'how do you think your prom differed from that of a US prom' and 'how important was the prom for your year group' to 'why do you think some people did not attend the prom' and 'did some people feel obliged to go the prom'.

Secondly a mini discussion group of three seventeen year old girls were invited to discuss how they would research this particular topic with their peers. A questionnaire was designed by the authors using the data generated by the discussion group (as well as the data from the interviews) and was underpinned by the notion of the high school prom being a ritual experience. The questionnaire was then piloted by the members of the discussion group and changes to the wording of the questionnaire were discussed and addressed. The questionnaire was then self-administered by the female friends from the discussion group to their peers to facilitate completion of the survey and to generate interest in the research topic. Using this research approach allowed the research topic to be addressed in a more holistic way as it not only allowed the adolescents an opportunity to add their own insights but it may also have provided a 
more complete knowledge of the research issue because of the creation of shared meaning with and within the respondent group.

Teenagers responding to the questionnaire were at the same high school in central Scotland and were intending to go to the high school prom. Of a possible 178 pupils, 132 intended to go to the prom and 86 pupils completed questionnaires. Of these 86 questionnaires, 81 were usable and 5 were incomplete $(n=81)$. This provided us with responses from over $60 \%$ of the attendees. The questionnaires included a number of open ended questions to generate a greater level of insight than may be obtained by simply employing a closed question approach.

The majority of adolescents completing the questionnaires were either sixteen or seventeen although a few of the youngest pupils were fifteen. Appropriate ethical consideration was given to this study with permission for the research to be conducted sought and given from the Head Teacher and on-going consent given by the adolescents involved in the project. The adolescents knew that they were not obliged to complete the questionnaires although interest in doing so appeared to be widespread. The research was topical as the questionnaires were distributed ten days before the prom was to take place and as such the event was widely anticipated.

The questionnaire data was statistically analysed using SPSS and the types of tests employed included cross tabulations, correlates (bivariates) and exploratory factor analysis. Correlations were used to determine significant relationships between the variables where $<$ p0.05. Likert scales, ranging from 1 strongly disagree to 5 strongly agree, were employed to gauge strength of agreement or disagreement with statements 
about the high school prom and the significance of the components of the ritual experience. The open ended question responses were also considered relative to the themes of this ritual event and contributed to an understanding of the meaning of this experience and its role in youth culture.

For the analysis of the interviews an interpretive analytic stance was adopted drawing on the transcriptions of the interviews and mini group discussion. The analysis of the data explored themes in the responses of adolescents using the constant comparative method described by Glaser and Strauss (1967) and analytic induction (Bryman and Burgess, 1994). Once the data was collected it was sorted before it was analysed. Each interview was examined to gain a holistic understanding of the respondent noting themes in the margin as they emerged (See Thompson and Hirschman, 1995). All the themes were reviewed through iterations of comparison and re-reading. The interpretations developed were as a consequence of the relationship between emerging insights and prior assumptions (Spiggle, 1994).

\section{Findings}

Initially the data presented here will provide a holistic view of the practice of the high school prom in the UK. This will include exploratory factor analysis to examine if there are different types of prom attendees with varying attitudes towards the high school prom. There then will follow a discussion, facilitated by the qualitative data, on the appropriation of the high school prom and the adoption or adaptation of the components of the ritual and the experience itself. The role of individual agency will also be explored. As the qualitative and quantitative stages of this research were 
designed to substantiate one another, the findings are structured around the key themes from the research rather than the phases of data collection.

\section{The Practice of the High School Prom Ritual Elements}

The ritual elements of the high school prom include artefacts (e.g. dress, shoes, limo), a script (e.g. what happens and in what order), performance roles (e.g. expected behaviour) and an audience (e.g. peers, family and a wider social network). The following section will explore how these manifest themselves at a UK prom and will conclude by examining, through exploratory factor analysis, if the ritual elements are perceived differently by the attendees.

\section{Artefacts}

Girls attending the UK prom appeared to invest in their artefacts to a greater extent than boys $(\mathrm{p}<0.05)$ with $70 \%$ of the quantitative sample (and their parents) spending $£ 80$ or more on their prom outfit (including dress, shoes, jewellery, make-up). 24\% of respondents spent in excess of $£ 150$ - with girls appearing to research the items necessary for this ritual event to a greater degree than boys and this was supported qualitatively:

"They [the girls] were planning it weeks before - and to be fair they looked stunning - they really made an effort."

Jamie, 19

Popular culture also played a more overt role for girls than for boys. Girls (to a greater extent than boys) were influenced by magazines when choosing an outfit, haircut or accessories for the prom $(\mathrm{p}<0.01)$. Girls were also significantly more likely than boys to travel in a limo to the event $(\mathrm{p}<0.01)$ and to spend more time preparing to go to the prom $(\mathrm{p}<0.01)$. As with the outdated debutante ball, there appeared to be a greater 
emphasis on the women and their attire perhaps suggesting their agency in this context was more constrained as opposed to dialectical (See Kozinets et al, 2004).

\section{Script}

Whilst the script of the US prom is evident in the data, two central components of the script appeared to have been lost in transition; that of the corsage exchange and the crowning of the prom king and queen. The latter does not feature as a component of the ritual scripts at all for this sample. This may be because the high school prom is viewed in the UK as a celebration for everyone leaving school (and as a consequence ought not to be considered more special for people who have been chosen as king and queen) and collectively, this particular element of the prom has been rejected (See for example Scott, 1994). Also the choosing of the king and queen would involve organisation and may require adult contribution. The celebration appears to remain more youth-focused without additional organisation or intervention. Only two of the interviewees had a corsage exchange. As corsages are associated with weddings in the UK it may be that corsages have not been adopted to minimise the associations between weddings and high school proms.

\section{Performance Roles}

Performance roles would include formal dancing and perhaps more importantly the role of a partner or boyfriend. Interestingly there was no consensus on prom 'dates'. Results from the questionnaire demonstrate that girls strongly disagreed that the purpose of the prom was to find a boyfriend $(\mathrm{p}<.001)$ and although this was not always supported in the qualitative data, '...there was a big emphasis on who had been asked to prom and who hadn't' (Rachel, 19), generally it was accepted that a 
prom date was not an essential component of the evening. Indeed the prom could be considered more as a an 'investment' to build individual social capital as there was a significant association between those who disagreed the purpose of the senior dance is to find a girlfriend or boyfriend and those that agreed that looking good and being remembered for a great outfit is important as it gives you more confidence the following year $(\mathrm{p}<0.05)$.

\section{Audience}

The girls' research, organisation and planning may possibly have been influenced by the perception and expectations of 'the audience':

"it's a competition of who has the nicest dress and the most expensive dress and who has the nicest way of getting there and who has the nicest date and who has the nicest hair - that is the thing [of most importance] - nothing about the actual night everyone is just comparing each other."

Hannah, 19

The audience for the prom was both internal (e.g. those attending the event and their families) and external (e.g. those likely to see pictures and hear anecdotal stories about the evening).

In some respects the internal audience could be considered as the harshest critic with the perception that ritual practice may be borrowed from elsewhere (e.g. weddings):

"It was complete red carpet stuff. We had our pictures taken on the red carpet outside the hotel and we all watched each other having our photo taken, commenting on the dress, the date - one girl was dressed in a wedding dress - seriously - and I thought 'Are you getting married tonight?'."

Keri, 20

Perhaps not surprisingly then girls comparatively with boys were more worried about wearing the same outfit $(\mathrm{p}<0.01)$ and looking individual $(\mathrm{p}<0.05)$. As Best $(2004)$ 
suggests there is agency in this context for girls to demonstrate their skills at assembling a range of signs or symbols. However, this agency was clearly constrained by the boundaries of what was acceptable or, to a certain degree, expected in this particular social environment (Kozinets et al, 2004).

The role of the external audience could not be underestimated either with those who agreed it was important to have a website or other type of space to show and share photos of the prom also agreeing that it was important to go to the prom because people were still talking about it the following year $(\mathrm{p}<0.01)$. As 'the minute people got home [from the prom] the first thing they did was put their pictures up on Bebo' (Rachel, 18) the longevity of the event and the significance of the audience was clearly important for some, if not all, the attendees. This in itself illustrates the role of the high school prom in youth culture given the growing significance and proliferation of social networking sites.

It appeared from both the qualitative and quantitative data that there may be differing perceptions of prom attendance. To explore this concept further, exploratory factor analysis was conducted. Byrne (2001) confirms the use of exploratory factor analysis as a tool to allow data to be explored in order to generate underlying factors that may exist within the data. This factor analysis was not designed to 'freeze meaning' (see Slater, 1997) but to illustrate the states between which adolescents would be likely to move. As discussion on identity formation in this postmodern age leads to references of multiple or fragmented identities instead of unitary or unchangeable ones (Featherstone, 2001) it is recognised that these segments are not stable. 
This exploratory analysis indicated that there are four factor groupings of prom attendees each with varying attitudes towards the high school prom and with differing propensities for the appropriation of cross-cultural ritual practice. These groups are as follows: those who were anxious about attending, those who thought it was an excuse for a party, those who were particularly image conscious and those who illustrated a need to belong (See Table 1). A discussion of ritual orientation and appropriation follows.

\begin{tabular}{|c|c|l|c|c|}
\hline $\begin{array}{c}\text { Type of Prom } \\
\text { Attendee }\end{array}$ & $\begin{array}{c}\text { Ritual } \\
\text { Orientation }\end{array}$ & \multicolumn{1}{|c|}{ Corresponding statements } & $\begin{array}{c}\text { Cronbach } \\
\text { Alpha }\end{array}$ & $\begin{array}{c}\text { Cumulative } \\
\text { loading }\end{array}$ \\
\hline Anxious & Global & $\begin{array}{l}\text { I am apprehensive about not finding someone to } \\
\text { go with } \\
\text { I am anxious about not looking as good as others } \\
\text { I will be nervous about making sure I get to sit } \\
\text { with friends } \\
\text { I am anxious about not being left out of my group }\end{array}$ & $\mathbf{. 7 0 1}$ & $\mathbf{7 4 . 5 \%}$ \\
\hline Celebratory & Local & $\begin{array}{l}\text { I am very excited and full of anticipation } \\
\text { I am looking forward to really dressing up } \\
\text { I am expecting one of the best nights out so far } \\
\text { I am really looking forward to sharing the } \\
\text { experience with all my friends }\end{array}$ & $\mathbf{. 6 5 6}$ & $\mathbf{7 8 . 8 \%}$ \\
\hline $\begin{array}{c}\text { Image } \\
\text { Conscious }\end{array}$ & 'Glocal' & $\begin{array}{l}\text { I am anxious about how my partner will feel if I } \\
\text { dance with someone else } \\
\text { I am worried about dancing with people who } \\
\text { can't dance } \\
\text { I am concerned about how much it will all cost } \\
\text { me } \\
\text { I'll probably get anxious about taking enough } \\
\text { good photos }\end{array}$ & $\begin{array}{l}\mathbf{. 7 0 6} \\
\text { I'll probably get upset if I don't get invited into a } \\
\text { limo } \\
\text { I am worried someone else will be wearing the } \\
\text { same outfit }\end{array}$ & $*$ \\
\hline Belong & 'Glocal' & $\mathbf{6 4 . 3 \%}$ & $*$ \\
\hline
\end{tabular}

*This is a correlate as opposed to a factor score as there are only two statements $\mathrm{p}<0.01$

Table 1: Types of Prom Attendees

\section{The Appropriation of the High School Prom}

Each of the groups identified in Table $\mathbf{1}$ have been classified as demonstrating a degree of appropriation or ritual orientation. That is, they have been categorised by the extent to which as groups they have adopted or adapted the high school prom. 
These groups and the relationship they have with the ritual elements will now be discussed in turn.

\section{The ‘anxious' group}

This group were anxious about attending the prom and focused on not finding a date, not looking as good as others and were most concerned about being left out of their group. These attendees placed greater emphasis on the traditional (conveyed) meaning of the prom ritual and as such exhibited a greater propensity for appropriation of the global ritual script without adaptation. As such, this 'anxious' group exhibited a global orientation. It would also seem that authenticity in terms of replicating (perceived) authentic US prom practice was significant in accepting the high school prom as part of youth culture for this group and that there were expectations of what adolescents should experience as a result of observing what happened elsewhere: “The American Prom on TV looks amazing but my school prom was nothing like that” Hannah, 19.

In this case, Hannah thinks her prom lacked authenticity as it did not match her perceptions of the way in which the prom is practiced in America and therefore the way in which she thinks it should have been interpreted in the UK. Lesley is disappointed she cannot adopt the US practice:

"My prom wasn't as full-blown as the American prom. We tried to get a limo but couldn't. The size of the hall it was in wasn't the same size as the one on the films. Ours wasn't quite as extravagant."

Lesley, 18 
Ashley also recognises that some attendees of her prom were disappointed as the UK prom did not meet the expectations of how a prom should be practised:

"I think our prom is very different to a US high school prom. A lot of people said before the prom that it was going to be like an American prom but after the prom lots of people said it was a big let down."

Ashley, 20

Agency in this context was 'blindly conformist' (Hetrick and Lozada, 1994). It may be, however, that the personal anxiety associated with the prom attendance manifest itself in the expectations of this ritual event. That is, these attendees were so anxious about performing appropriately that they expected the prom to reflect their own investment. Interesting to note is Gidden's (1991) reflection that ritual often produces anxiety rather than alleviating it as it represents a major transition in life. Perhaps the anxious group were more aware of the significance of this transitional phase.

\section{The 'celebratory' group}

Those who thought the prom was an excuse to celebrate however were less concerned with the adoption of the US prom and were excited, full of anticipation and were just really looking forward to dressing up. In this sense the 'celebratory' group displayed a greater preference for the local adaptation of the prom ritual, reworking it to complement their calendar of end-of-year social events and displayed a local orientation which was both creative and subversive in practice.

"I suppose ours was a prom but it was more like a big party - a sort of going away. It was a disco in a different location - although we were wearing gowns and kilts and we had a limo - whereas at a disco you wouldn't make that much of an effort. [It was] a glorified disco I suppose."

Ashley, 20 
There also appeared to be an acceptance that depending on the locale of the prom that the custom would be different. Additionally the US prom and the associated practices were recognised as being stressful or pressurised:

"I think it's important to have one [a prom] because you get to do the social thing with people from school but I also think that it's important to have fun - but not to try hard to have fun and just enjoy yourself without any pressure of the American type prom."

Joanne, 18

There also appeared in this group to be more recognition of re-working the prom to the local culture:

"We had stretch hummers, so that definitely compares [to the US high school prom]. They get more dressed up [but] we put a Scottish slant on it because they usually have a theme like 'Under the Sea' or things like that. We had a caleigh [Scottish dancing] and then just a disco."

Lorna, 18

\section{The 'image conscious' and those who 'needed to belong'}

This reworking was less apparent in the groups who were 'image conscious' or those who 'needed to belong'. These groups tended to focus on specific aspects of the prom. For example, if the attendees were image conscious they focused on getting 'good' photos taken whereas those who needed to belong indicated that they were anxious about feeling left out of their group (e.g. not being asked to share a limo). Both these groups demonstrated a desire to adopt specific characteristics of the prom ritual whilst remaining faithful to the local cultural narratives and could be said to have a more 'glocal' orientation. The notion of why taking pictures is so important for the 'image conscious' was elaborated on by Yasmin:

"Bebo stalking goes to the extreme [with prom pictures]. You have to have pictures galore...so that people who didn't go you make it look like it was more fun. When you put your pictures up you have to have millions...and you have to get pictures of 
everyone. Even if you don't know these people you just have to - and you are very glam - it's not just like going to a normal party...."

Of course not all prom attendees will fall neatly into one category and it is likely that there may be some overlapping (e.g. Lorna in this sample appeared to be celebratory as well as image conscious). It may be that the degree of agency varies depending on the changing social circumstances in which the ritual is being performed e.g. if a girl is unexpectedly asked to the prom by a boy she may become more anxious whereas previously when just attending with friends her outlook would have been more celebratory. The exploratory factor analysis however, does confirm the presence of common groupings which could be used for future research in this area to explore the extent to which the prom is more likely to be adopted (globalization) or adapted (localised) depending on motivations for attending.

\section{The Role of Individual Agency}

Within youth culture, the notion of agency is well documented. For example, teenagers are known to engage in imaginative acts of defiance or practices of (re) appropriation (Russell and Tyler, 2005). These practices, however, may depend on the role (s) adopted by those engaged in the cultural act or process. It was evident, for example, that attendees in this sample used the prom as an opportunity to change people's opinion of them and that this could be perceived to have been a success. For example, Keri reflects on how her perception of an attendee changed as a consequence of the school prom:

'Some people looked amazing - you know those who walked along at school really quietly - they were still quite quiet at the formal [prom] but I think they had made a real effort to change people's perception of them. Some of them looked fantastic you'd never seen them out of tracksuit bottoms and a hoodie.'

Keri, 20 
There was also opportunity to build social capital for the attendees depending on their individual agency in relation to social networking sites:

"More pictures equal more [perceived] fun - and you are capturing more of it...the more pictures you have, it looks like it was more of a night. If you only put up five pictures it looks like it was a bit of a pants night. The more people you have in the pictures it looks like you have more friends. If you have massive group photos that's good."

Yasmin, 18

Adolescent agency was also evident in the way in which local adaptations of high school prom allowed this ritual event to be reworked. Practices included giving special gifts within friendship groups before going to the prom to mark the occasion and also added to the known script (and may further illustrate the symbolic meaning of gift giving see, for example, Belk, 1996). There also appeared to be special roles for some parents which may reinforce the way in which this event, positioned as an aspect of youth culture, can be appropriated as part of a more dominant (familial) culture.

'My parents came home from work and we had a champagne reception for us [other parents and five girls in friendship group] before the prom. I think it was probably quite a big thing for them too.'

Sarah, 20

\section{Conclusion}

This paper has shown not only adolescents' appropriation of a globalizing cultural ritual but how this appropriation appears to differ by attitudes to attending, in this particular case, the high school prom. Previous studies (See Ger and Belk, 1996) have alluded to globalization and appropriation but have tended only to provide examples of brand related products. This paper contributes to our existing understanding of appropriation by illustrating not only the role of agency in appropriation but the extent to which homogenization and heterogenization are interconnected processes 
(Robertson, 1994; Robertson and White, 2005) and that there can be varying degrees of appropriation (e.g. global, local or glocal) even for the same ritual practice. That is, our understanding of how and in what ways local practice has been developed and cocreated in the context of the global has been illustrated here. Agency has been identified as both creative and conformist (See Kozinets et al, 2004) and as such has contributed to our notion of the ways in which the degree of glocalisation is influenced by social circumstances. Diagram 1 illustrates the key concepts and interrelationships that have been explored whilst investigating the appropriation of the high school prom in the UK.

\section{Diagram 1: Concepts and Inter-relationships Associated with Appropriation}

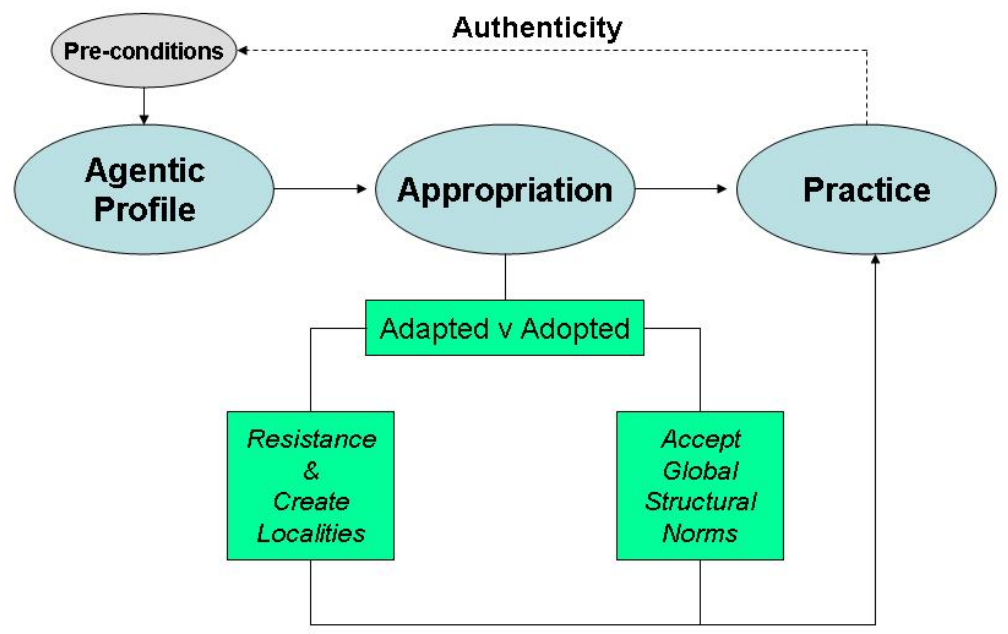

The existing local practice in the UK which would have involved a disco in the school hall has not been entirely lost in the adoption or adaption of the high school prom and as such appropriation of this US ritual has not completely replaced previous tradition (although it has certainly added to the notion of how to celebrate the end of school). The adaptation (or co-shaping) of the high school prom has seen a 'Scottish slant' 
reported by those attending Scottish proms and this has been reflected in artefacts (e.g. kilts) and performance roles (e.g. caleigh dancing) illustrating that the creation of localities is indeed a standard component of globalization (Giulianotti and Robertson, 2007). Examination of other ritual practices, such as the coming of age celebrations (e.g. confirmation) mentioned earlier may also provide a more holistic understanding of the diversity of practice in relation to (re) appropriation.

Interestingly the findings suggest that authenticity in the context of globalizing rituals is twofold. That is all the adolescents did not necessarily negotiate authenticity when appropriating the high school prom as suggested by Arthur (2006). Rather a number of attendees considered that when their prom did not replicate their perceptions of a US prom that their prom lacked authenticity. This contributes to our understanding of adolescent agency as it elaborates on the way in which co-creation is influenced by both a dominant force (US producers) and conformist behaviour. Additional work on the aspects of perceived authenticity and practice authenticity and the role of appropriation in this situation would contribute further to our understanding of glocalisation. Research which considers the factors affecting agency (See Titma et al, 2007) such as individual goals, control within peer groups, self esteem and previous experiences (taking into account the role of individual agency) would also allow a development of the typology explored in Table 1 and the framework illustrated in

\section{Diagram 1.}

As this paper has focused solely on the attendees of the high school prom in the UK, a study that considers the anti or non consumption of this ritual event and focuses on how youth culture in this situation critically resists this practice (see Giulianotti and 
Robertson, 2007) could add to our understanding of both (re) appropriation and agency in relation to the high school prom.

Finally, further research could also explore the concept of multiple identities or selves as the prom can be a way in which teenagers can transform themselves literally overnight. The example of the girl who changed out of her tracksuit into a ball gown is evidence of this. The prom as a 'critical moment' (See Thomson et al, 2002) also needs further exploration as critical moments in 'inventing adulthoods' appear to be socially structured and could feature the high school prom. This will both develop and enhance our understanding of this cultural practice as a coming of age event. If, as Newcombe et al (2000) suggest, extended memories often include prom night the longer term significance of the UK high school ritual experience as a milestone may yet to be fully appreciated.

\section{References}

Arnould, E.J. and Thompson, C.J. (2005) "Consumer Culture Theory (CCT): Twenty Years of Research”, Journal of Consumer Research, Vol.31, pp.868-881

Arthur, D. (2006) "Authenticity and consumption in the Australian Hip Hop culture”, Qualitative Market Research: An International Journal, Vol. 9 No.2, pp. 140-156

Belk, R.W. (1990) "Halloween: An Evolving American Consumption Ritual", Advances in Consumer Research, Vol.17, pp.508-517

Belk, R.W. (1996) “The Meaning of Gifts and Greetings”, Advances in Consumer Research, Vol.23, pp.13

Belk, R.W. (2004) “Men and their Machines”, Advances in Consumer Research, Vol.31, pp. 273-278

Best, A. L. (2000) Prom Night: Youth, Schools and Popular Culture New York: Routledge/Farmer

Best, A. L. (2004) "Girls, Schooling and the Discourse of Self Change: Negotiating Meaning of the High School Prom”. In: Harris, A. All About the Girl: Culture Power and Identity, New York: Routledge, Chapter 17

Bonsu, S. (2001) "Death Becomes Us: Negotiating Consumer Identities through Funerary Products in Ghana, Advances in Consumer Research, Vol.28, pp.340-346

Brake, M. (1985) Comparative Youth Culture London: Routledge

Bryman, A. and Burgess, R.G. (1994) Analyzing Qualitative Data. London: Routledge

Bynner J. (1997) "Agenda for youth research in the next century: a British Perspective”, Young, Vol. 5, No. 4, pp.34-49 
Byrne, B.M. (2001) Structural Equation Modelling With AMOS Basic Concepts, Applications and Programming London: Lawrence Erlbaum Associates

Chun, S., Gentry, J.W. and McGinnis, L.P. (2004) "Cultural Differences in Fan Ritualization: A Cross-Cultural Perspective of the Ritualization of American and Japanese Baseball Fans", Advances in Consumer Research, Vol. 31, pp. 503-508

Chun, S. Gentry J.W. and McGinnis L.P. (2005) "Ritual Aspects of Sports Consumption: How Do Sports Fans Become Ritualized?”, Asia Pacific Advances in Consumer Research, Vol.6, pp.331-336

Close, A. and Zinkhan G.M. (2006) "A Holiday Loved and Loathed: A Consumer Perspective of Valentine's Day”, Advances in Consumer Research, Vol.33, pp.356365

Duffy, M. (2007) "Fizz, frocks and limos: get ready for the ultimate party", The Herald, September $8^{\text {th }}$, pp.15

Eckhardt, G.M and Mahi, H (2004) "The Role of Consumer Agency in the Globalization Process in Emerging Markets”, Journal of Macromarketing, Vol.24, No.2, pp.136-146

Erikson, E.H. (1968) Identity: Youth and Crisis New York: Norton

Escalas, J.E. (1993) "The Consumption of Insignificant Rituals: A Look at Debutante Balls”, Advances in Consumer Research, Vol. 20, pp.709-716

Featherstone, M. (2001) "Postnational Flow, Identity Formation and Cultural Space". In, E.B. and Sternberg Y (eds) Identity, Culture and Globalization, Leiden: Brill pp.494-526

Fernandez, K. V. and Veer, E. (2004) "The Gold that Binds: The Ritualistic use of Jewellery in a Hindu Wedding, Advances in Consumer Research, Vol. 31, pp.55

Fien, J. Neil, C. and Bentley, M. (2008) "Youth Can Lead the Way to Sustainable Consumption”, Journal of Education for Sustainable Development, Vol. 2, No.1, pp.51-60

Fischer, E. and Gainer B. (1993) "Baby Showers: A Rite of Passage in Transition", Advances in Consumer Research, Vol.20, pp.320-324

Ger, G. and Belk, R.W. (1996) "I'd Like to Buy the World a Coke: Consumptionscapes of the Less Affluent World”, Journal of Consumer Policy, Vol. 19, pp.271-304

Giddens, A. (1991) Modernity and Self Identity: Self and Society in the Late Modern Age Cambridge: Polity Press

Giulianotti, R. and Robertson, R. (2007) "Forms of Glocalisation: Globalization and the Migration Strategies of Scottish Football Fans in North America”, Sociology, Vol. 1, No.1, pp.133-152

Glaser, B and Strauss, A. (1967) The Discovery of Grounded Theory: Strategies for Qualitative Research, Chicago: Aldine

Hektner, J.M. (1995) "When Moving Up Implies Moving Out: Rural Adolescent Conflict in the Transition to Adulthood", Journal of Research in Rural Education Vol. 11, No.3, pp3-14

Hetrick, W.P. and Lozada, H.R. (1994) "Constructing the Critical Imagination: Comments and Necessary Diversions”, Journal of Consumer Research, Vol.21, pp.548-558

Jeffries, S. (2004) “Give Up the Ghosts", The Guardian, 29 $9^{\text {th }}$ October

Johnson, B.R. and Onwuegbuzie, A.J. (2004) "Mixed Methods Research: A Research Paradigm Whose Time Has Come”, Educational Researcher, Vol. 33, No.7, pp.14-26 
Kjeldgaard, D. and Askegaard, S. (2006) “The Glocalization of Youth Culture: The Global Youth Segment as Structures of Common Difference”, Journal of Consumer Research, Vol. 33, pp.231-247

Kozinets, R., Sherry, J.F., Storm, D., Nuttavuthist, K. and Deberry-Spence, B. (2004) "Ludic Agency and Retail Spectacle”, Journal of Consumer Research, Vol.31, pp.658-672

Lukose, R. (2005) “Consuming Globalization: Youth and Gender in Kerala, India”, Journal of Social History, Vol. 38, pp.915-935

McAlexander, J. H. (1991) "Divorce, The Disposition of the Relationship and Everything”, Advances in Consumer Research, Vol.18, pp. 43-48

Moran-Ellis, J., Alexander, V.D., Cronin, A., Dickson, M., Fielding, J., Sleney J. and Thomas, H. (2006) 'Triangulation and integration: processes, claims and implications', Qualitative Research, Vol. 6, No.1, pp.45-59

Newcombe, N. S., Drummey, A.B., Fox, N.A., Lie, E. and Ottinger-Alberts, W. (2000) "Remembering Early Childhood: How Much, How and Why (or Why Not), Current Directions in Psychological Science, Vol. 9, No. 2, pp55-58

Ostergaard, P., Fitchett, J.A. and Jantzen, C. (1999) "On Appropriation and Singuralisation: Two Consumption Processes”, Advances in Consumer Research, Vol.26, pp.405-409

Otnes, C. and Lowrey T.M. (1993) "Til Debt Do Us Part: The Selection and Meaning of Artifacts in the America Wedding”, Advances in Consumer Research, Vol.20, pp.325-329

Ozanne, J. L. (1992) "The Role of Consumption and Disposition During Classic Rites of Passage: The Journey of Birth, Initiation and Death”, Advances in Consumer Research, Vol.19, pp. 396-403

Pollay, R.W. (1987) "It's The Thought That Counts: A Case Study in Xmas Excesses”, Advances in Consumer Research, Vol.14, pp.140-143

Prakash, A. and Hart, J.A. (2000) Coping with globalization. New York: Routledge Pyke, N. and Bloomfield, S. (2004) "The high school prom arrives in UK (via stretch limo, naturally)”, The Independent, Sunday $11^{\text {th }}$ July, Education News

Ritzer, G. (1993). The McDonaldization of Society. Newbury Park: Pine Forge Press Robertson, R. (1994) 'Globalization or Glocalisation?', Journal of International Communication Vol.1, No.1, pp.33-52

Robertson, R. (1995) "Glocalisation: Time-Space and Homogeneity-Heterogeniety" In Global Modernities Ed. Featherstone, M., Lash, S. and Robertson, R. (1995) pp.2544

Robertson. R and White, K.E. (2005) "Globalization: Sociology and CrossDisciplinarity' in C.Calhoun, C. Rojek and B.S. Turner (Eds) The Sage Handbook of Sociology pp.345-366 London: Sage

Rogers R.A. (2006) "From Cultural Exchange to Transculturation: A Review and Reconceptualiztion of Cultural Appropriation”, Communication Theory, Vol.16, pp.474-503

Rook, D. W. and Levy S.J. (1983) "Psychosocial Themes in Consumer Grooming Rituals”, Advances in Consumer Research, Vol.10, pp.329-333

Rook, D.W. (1985) “The Ritual Dimension of Consumer Behavior”, Journal of Consumer Research, Vol. 12, pp.251-264

Russell, R. and Tyler M. (2005) "Branding and Bricolage: Gender, consumption and translation”, Childhood, Vol. 12, No. 2, pp.221-237

Ruth, J.A. (1995) "Sad, Glad and Mad: The Revealing Role of Emotions in Consumer Rituals”, Advances in Consumer Research, Vol.22, pp.692 
Sale, J.E.M., Lohfeld, L.H. and Brazil, K. (2002) "Revisiting the QuantitativeQualitative Debate: Implications for Mixed Methods Research", Quality and Quantity, Vol.36, pp.43-53

Scott, L. (1994) "The Bridge from Text to Mind: Adapting Reader-Response Theory to Consumer Research”, Journal of Consumer Research, Vol. 21, pp.461-480

Shugart, H. (1997) "Counterhegemonic acts: Appropriation as a feminist rhetorical strategy, Quarterly Journal of Speech, Vol. 83, pp.210-229

Slater, Don (1997) Consumer Culture and Modernity Cambridge: Polity

Spiggle, S. (1994) "Analysis and Interpretation of Qualitative Data in Consumer Research”, Journal of Consumer Research, Vol. 21, pp.491-503

Thompson, C.J. and Hirschman, E. (1995) "Understanding the Socialized Body: A Poststructuralist Analysis of Consumers' Self-Conceptions, Body Images and SelfCare Practices”, Journal of Consumer Research, Vol. 22, pp.319-153

Thompson, C.J. and Arsel, Z. (2004) "The Starbucks Brandscape and Consumers (Anticorporate) Experiences of Glocalization”, Journal of Consumer Research, Vol. 31, pp.631-642

Thomson, R., Bell, R., Holland, J., Henderson, S., McGrellis, S. and Sharpe, S. (2002) "Critical Moments: Choice, Chance and Opportunity in Young People's Narratives of Transition”, Sociology, Vol. 36, pp.335-354

Titma, M., Tuma, N.B. and Roots, A. (2007) “Adolescent agency and adult economic success in a transitional society”, International Journal of Psychology, Vol.42, No.2, pp.102-109

Tomlinson, J. (1991) Cultural Imperialism Baltimore: John Hopkins University Press Watson, J. (1998) "Why did you put that there?": Gender, Materialism and Tattoo Consumption”, Advances in Consumer Research, Vol.25, pp.453-460 